\title{
Role of Plasma Osteopontin Level as a Predictor of Hepatic Fibrosis Regression and Response to Antiviral Treatment in Patients with Chronic HBV or Chronic HCV Infection
}

\author{
Heba A. Osman ${ }^{*}$, Ali A. Ghweil1, Ashraf Khodeary² \\ ${ }^{1}$ Tropical Medicine and Gastroenterology Department, Faculty of Medicine, South Valley University, Qena, Egypt \\ ${ }^{2}$ Clinical Pathology Department, Faculty of Medicine, Sohag University, Sohag, Egypt \\ Email: ^drheba.saleh@med.svu.edu.eg
}

How to cite this paper: Osman, H.A., Ghweil, A.A. and Khodeary, A. (2018) Role of Plasma Osteopontin Level as a Predictor of Hepatic Fibrosis Regression and Response to Antiviral Treatment in Patients with Chronic HBV or Chronic HCV Infection. Open Journal of Gastroenterology, 8 , 434-447.

https://doi.org/10.4236/ojgas.2018.812045

Received: October 27, 2018

Accepted: December 1, 2018

Published: December 4, 2018

Copyright $\odot 2018$ by author(s) and Scientific Research Publishing Inc. This work is licensed under the Creative Commons Attribution International License (CC BY 4.0).

http://creativecommons.org/licenses/by/4.0/

\section{(c) (i) Open Access}

\begin{abstract}
Background: Hepatitis B virus and Hepatitis $C$ virus infection is one of the public health problems in Egypt. So we aimed to evaluate the efficacy of serum osteopontin as predictor of hepatic fibrosis regression and virological response in patients with chronic HBV or HCV infection. Methods: This study has been conducted on $74 \mathrm{HBeAg}+$ ve chronic HBV infection, 74 chronic HCV infection and 74 healthy controls. HBV patients treated with Entecavir. HCV patients treated with sofosbuvir, daclatasvir with or without ribavirin. One year post $\mathrm{HBeAg}$ seroconversion and 3 months after end of regular antiviral treatment for patients with chronic HBV and chronic HCV infection respectively, hepatic condition was reevaluated. Results: $14.9 \%$ of patients with HBV, failed to achieve undetectable HBV DNA or HBeAg seroconversion and $2.7 \%$ of patients with HCV infection, failed to achieve SVR. In chronic HBV, pretreatment high serum osteopontin predict failure of virological response and hepatic fibrosis regression at a cutoff $>115.5$, with $90.91 \%$ sensitivity, $82.54 \%$ specificity. Also high degree of liver stiffness predicts failure of hepatic fibrosis regression at a cutoff $>8.7$, with $81.8 \%$ sensitivity, 73\% specificity. Conclusions: In chronic HBV infection low osteopontin predicts good virological response and hepatic fibrosis regression. But it has no role in predicting SVR or hepatic fibrosis regression in chronic HCV infected patients.
\end{abstract}

\section{Keywords}

Osteopontin, Hepatic Fibrosis, HBV, HCV 


\section{Introduction}

Egypt has the highest prevalence of hepatitis $\mathrm{C}$ virus (HCV) infection worldwide [1].

Chronic hepatitis $\mathrm{C}$ virus infection is the main cause of end-stage liver disease with liver cirrhosis and hepatocellular carcinoma in Egypt, it's responsible for chronic hepatitis in about $80 \%$ of the infected patients, of them about $20 \%$ develop liver cirrhosis of them about $6 \%$ develop decompensated liver disease and $5 \%$ of the patients with liver cirrhosis develop hepatocellular carcinoma [2].

Sofosbuvir, daclatasvir, with or without ribavirin combination are safe and effective in treatment of chronic hepatitis C virus infection in Egypt [3].

Sustained virological response after 3 months of regular treatment achieved in about $95 \%$ of patients in the easy-to-treat group who received Sofosbuvir and daclatasvir, and reach about $92 \%$ in the difficult-to-treat group who treated with Sofosbuvir, daclatasvir, and ribavirin [3].

Direct acting antiviral (DAA) combinations proved to cause obvious improvements in hepatic laboratory parameters with good clinical outcomes in chronic hepatitis $\mathrm{C}$ virus treated patients [4].

The side effects reported post treatment with sofosbuvir, daclatasvir, and ribavirin combination range from mild adverse events as anemia, fatigue, headache, and itching to severe side effects as hepatocellular carcinoma and hepatic encephalopathy which reported in patients with advanced liver disease [5].

Hepatitis B virus (HBV) infection is one of the public health problems in Egypt [6].

About 350 million patients in Egypt have chronic hepatitis B virus infection and more than 1 million die from liver cirrhosis and hepatocellular carcinoma annually [7].

The aim of therapy of patients with chronic hepatitis B virus infection is to preventthe liver disease progression by suppressing hepatitis B virus DNA replication [8].

The available oral antiviral drugs for treatment of chronic HBV infected patients include nucleos(t)ide analogue as lamivudine, adefovir, entecavir, telbivudine and tenofovir [9].

Effective antiviral treatment of chronic hepatitis B virus infection reduced the risk of long-term complications and improved patient survival [9].

Entecavir is a cyclopentyl guanosine analogue with a potent inhibitory effect on HBV DNA replication [10].

Entecavir is effective in the treatment of patients with either $\mathrm{HBeAg}$ positive or HBeAg negative chronic hepatitis B [11].

Treatment with Entecavir cause viral suppression with significant improvement in hepatic fibrosis and liver functions biochemical parameters [12].

Osteopontin, is a secreted Phosphoprotein involved in different hepatic pathological conditions such as inflammation, immunity, angiogenesis, liver fibrosis progression, invasion and metastasis of HCC [13]. 
In the liver, Osteopontin exists normally in the epithelial bile duct [14].

Osteopontin pathologically expressed in Kupffer cells, hepatic macrophages and hepatic stellate cells in areas of liver necrosis [15].

Osteopontin has a role in many liver diseases as acute liver cell failure [16], nonalcoholic fatty liver diseases [17], alcoholic liver diseases [18], hepatic fibrosis with chronic hepatitis B [19], and chronic hepatitis C [20]. Also, Osteopontin considered as a better prognostic marker for early hepatocellular carcinoma compared with alpha-fetoprotein [21].

Hepatic fibrosis is the most dangerous complication of chronic hepatic disease that finally leads to cirrhosis with subsequent complications [22].

So, in this study we try to evaluate the effect of antiviral treatment in decreasing serum Osteopontin level as a marker of improving hepatic fibrosis and as a pretreatment marker to predict response to treatment in patients with chronic hepatitis $\mathrm{B}$ or chronic hepatitis $\mathrm{C}$ virus infection.

\section{Aim of the Work}

The current study aimed to evaluate the effect of antiviral treatment in decreasing serum Osteopontin level as a marker of improving hepatic fibrosis and as a pretreatment marker to predict response to treatment in patients with chronic hepatitis B or chronic hepatitis $\mathrm{C}$ virus infection.

\section{Patients and Methods}

This prospective comparative case-control study has been conducted on 222 subjects of them 74 naive patients with $\mathrm{HBeAg}$ positive chronic $\mathrm{HBV}$ infection with different degree of hepatic fibrosis (F0, F1, F2, F3, $\geq F 4$ ), and 74 patients with chronic hepatitis $\mathrm{C}$ virus infection with variable degree of liver stiffness and 74 age and sex matched healthy control for assessment of normal serum osteopontin. All patients attend out patients' clinic of Tropical Medicine and Gastroenterology Departments during the period from July 2017 till August 2018.

All patients with chronic HBV infection were treated with Entecavir $0.5 \mathrm{mg}$ or $1 \mathrm{mg}$ once daily oral on empty stomach according to hepatic condition. Patients were treated according to EASL 2017 guidelines for HBV infection treatment [23].

Patients with chronic HCV infection were treated with DAAS in the form of sofosbuvir $400 \mathrm{mg}$ and daclatasvir $60 \mathrm{mg}$ with or without ribavirin (800 - 1200 $\mathrm{mg}$ ) once daily for 12 weeks. Patients were treated according to the Egyptian protocol for treatment of chronic hepatitis $\mathrm{C}$ virus infection, which follow EASL 2015 guidelines for treatment of HCV infection [24].

At base line all included patients with chronic HBV infection or chronic HCV infection subjected to complete history taking, full clinical examination, liver function tests, liver fibrosis assessment (F0 - $\geq F 4)$ using fibroscan, and serum Osteopontin measurement as a marker of liver fibrosis.

One year post $\mathrm{HBeAg}$ seroconversion and 3 months after end of regular anti- 
viral treatment for patients with chronic HBV infection and chronic HCV infection respectively, all patients are reevaluated clinically, laboratory and radiological for reassessment of improvement in hepatic condition.

Patients with HBV and HCV co-infection, $\mathrm{HBeAg}$ negative chronic hepatitis $B$, hepatitis D virus infection, human immunodeficiency virus, malignancy anywhere in the body, triphasic CT imaging of hepatocellular carcinoma (HCC) or history of HCC, excessive alcohol consumption more than 21 drinks per week for men and more than 14 drinks per week for women, autoimmune diseases, any liver diseases other than chronic hepatitis $B$ or chronic hepatitis $C$ virus infection, diabetes mellitus, kidney, heart or chest diseases, pregnancy were excluded from the study also chronic hepatitis $\mathrm{C}$ virus infected patients with high serum bilirubin $(>\mathrm{mg} / \mathrm{dl})$, low serum albumin level $(<2.8 \mathrm{gm} / \mathrm{dl})$, low platelet count $\left(<50 \times 10^{3} / \mu \mathrm{l}\right)$ with marked impaired INR $(\geq 1.7)$ were excluded from the study as they were out of the treatment protocol.

\subsection{Laboratory Workup}

\subsubsection{Sampling}

$8 \mathrm{ml}$ of venous blood were collected from each patients under aseptic precautions and divided in 4 tubes: 1) 2 tubes containing EDTA (sterile EDTA containing Vacutainer) one for platelet count used directly and the other for HBV-DNA centrifuged, separated in sterile tube and frozen at $-20^{\circ} \mathrm{C}$ till the time of the assay. 2) Plain glass tube for liver function tests, then after clotting, the tube was centrifuged at $3000 \mathrm{rpm}$ for $5 \mathrm{~min}$ and then the serum was separated to be used for estimation of liver function (including liver enzymes, albumin, bilirubin-total and direct) and serum Osteopontin. 3) Sodium citrate containing tube (Vacutainer) for prothrombin time, prothrombin concentration and INR.

\subsubsection{The Laboratory Tests}

1) The platelet count was done by Celtak haematology analyzer (Nihon Kohden, Japan).

2) The liver function tests including (total and direct bilirubin, serum albumin, AST and ALT) were done by BT 1500 full automated chemistry analyzer (Bioticnica, Italy).

3) The prothrombin time, prothrombin concentration and INR was done using Thromborel S kits (Siemens, Germany) using BE coagulator (Germany).

4) HBV-DNA was done by StepOnePlus ${ }^{\mathrm{TM}}$ Real-Time PCR System (ThermoFisher Scientific, USA) using Taqman PCR mastermix (ThermoFisher Scientific, USA) after DNA extraction by Qiagen kit (Qiagen, Inc., USA) and according the manufacture's pamphlet.

$5 \mathrm{ml}$ of venous blood obtained from all subjects in plain tube and centrifuged then the serum is separated for the laboratory tests:

5) HCV antibodies and HBsAg is done by the MiniVidas fully automated immunoassay system (Biomerieux, France).

6) Osteopontin is estimated by Abcam's osteopontin human ELISA (En- 
zyme-Linked Immunosorbent Assay) kit is an in vitro assay for the quantitative measurement of human osteopontin in serum and plasma.

This assay use an antibody specific for human osteopontin coated on a 96-well plate. Standards and samples are pipetted into the wells and osteopontin present in a sample is bound to the wells by the immobilized antibody. The wells are washed and biotinylated anti-human osteopontin antibody is added. After washing away unbound biotinylated antibody, HRP-conjugated streptavidin is pipetted to the wells. The wells are again washed, a TMB substrate solution is added to the wells and color develops in proportion to the amount of osteopontin bound. The stop solution changes the color from blue to yellow, and the intensity of the color is measured at $450 \mathrm{~nm}$.

\subsection{Statistical Analysis}

Data were analyzed using Statistical Program for Social Science (SPSS) version 15.0. Quantitative data were expressed as mean \pm standard deviation (SD). Qualitative data were expressed as frequency and percentage. The following tests were done: Independent-samples t-test of significance: was used when comparing between two means, Chi-square test: was used when comparing between non-parametric data, A one-way analysis of variance (ANOVA): when comparing between more than two means, Post Hoc test: was used for multiple comparisons between different variables.

Probability (p-value)

- p-value $<0.05$ was considered significant.

- p-value $<0.001$ was considered as highly significant.

- p-value $>0.05$ was considered insignificant.

\section{Results}

The present study included 222 subject classified to 3 groups, the first group include 74 apparent healthy control, the second group include 74 naive chronic HBV infected patient with their mean ages were $50.4 \pm 9.1 ; 35$ (47.3\%) females and $39(52.7 \%)$ males of them 25 (33.8\%) had mild viral load, 25 (33.8\%) had moderate viral load and 24 (32.4\%) had high viral load.

The third group include 74 chronic HCV infected patient with their mean ages were $52.2 \pm 9.5 ; 33(44.6 \%)$ females and $41(55.4 \%)$ males of them 25 (33.8\%) had mild viral load, 25 (33.8\%) had moderate viral load and $24(32.4 \%)$ had high viral load.

The pretreatment laboratory data, mean serum osteopontin level and mean hepatic fibrosis level of our included patients with chronic hepatitis B and chronic hepatitis $\mathrm{C}$ virus infection were discussed in Table 1.

In patients with chronic HBV infection, Enticavir $0.5 \mathrm{mg} /$ day or $1 \mathrm{mg} / \mathrm{day}$ reviles that, 11 (14.9\%) of patients failed to achieve undetectable HBV DNA by real time PCR or HBeAg seroconversion. However, 2 (2.7\%) of patients with chronic HCV infection failed to achieve SVR three months after end of regular 
Table 1. Demographic data and baseline laboratory data of patients with chronic hepatitis $\mathrm{B}$ and chronic hepatitis $\mathrm{C}$.

\begin{tabular}{|c|c|c|}
\hline Variables & $\begin{array}{c}\text { Chrnic HBV } \\
(\mathrm{N}=74)\end{array}$ & $\begin{array}{c}\text { Chrnic HCV } \\
(\mathrm{N}=74)\end{array}$ \\
\hline Age (years) Mean \pm SD & $50.4 \pm 9.1$ & $52.2 \pm 9.5$ \\
\hline \multicolumn{3}{|l|}{ Sex $(N \%)$} \\
\hline - Male & $39(52.7 \%)$ & $41(55.4 \%)$ \\
\hline - Female & $35(47.3 \%)$ & $33(44.6 \%)$ \\
\hline \multicolumn{3}{|l|}{ Viral load } \\
\hline \multirow[t]{2}{*}{ - Mild } & $25(33.8 \%)$ & $25(33.8 \%)$ \\
\hline & $(16-100,000)$ & $(20,000-100,000 \mathrm{IU} / \mathrm{ml})$ \\
\hline - Moderate & $25(33.8 \%)$ & $25(33.8 \%)$ \\
\hline \multirow{3}{*}{ - High } & $(100,000-1,000,000)$ & $(100,000-500,000 \mathrm{IU} / \mathrm{ml})$ \\
\hline & $24(32.4 \%)$ & $24(32.4 \%)$ \\
\hline & $(>1,000,000)$ & $(>500,000 \mathrm{IU} / \mathrm{ml})$ \\
\hline Responder patients (N\%) & $63(85.14 \%)$ & $72(97.30 \%)$ \\
\hline $\begin{array}{l}\text { Pretreatment degree of liver } \\
\text { stiffness }(\mathrm{kpa})(\text { Mean } \pm \mathrm{SD})\end{array}$ & $7.19 \pm 3.11$ & $7.36 \pm 3.26$ \\
\hline Osteopontin (Mean \pm SD) & $82.31 \pm 45.42$ & $78.73 \pm 48.02$ \\
\hline AST $(\mathrm{U} / \mathrm{L})(\mathrm{Mean} \pm \mathrm{SD})$ & $62.68 \pm 18.93$ & $48.27 \pm 22.42$ \\
\hline $\operatorname{ALT}(\mathrm{U} / \mathrm{L})(\mathrm{Mean} \pm \mathrm{SD})$ & $67.72 \pm 21.81$ & $51.62 \pm 26.07$ \\
\hline Bilirubin $(\mathrm{mg} / \mathrm{dl})($ Mean $\pm \mathrm{SD})$ & $1.18 \pm 0.23$ & $1.11 \pm 0.29$ \\
\hline Albumin $(\mathrm{g} / \mathrm{dl})($ Mean $\pm \mathrm{SD})$ & $3.99 \pm 0.52$ & $4.08 \pm 0.64$ \\
\hline Platelets $\left(\times 10^{3} / \mathrm{ul}\right)($ Mean $\pm \mathrm{SD})$ & $213.84 \pm 73.81$ & $214.51 \pm 77.58$ \\
\hline INR $($ Mean \pm SD $)$ & $1.08 \pm 0.15$ & $1.07 \pm 0.16$ \\
\hline
\end{tabular}

antiviral therapy with sofosbuvir $400 \mathrm{mg}$ and daclatasvir $60 \mathrm{mg}$ with or without weigh-based ribavirin (800 - $1200 \mathrm{mg}$ ) once daily.

By comparing laboratory data and liver stiffness before and after therapy in patients with chronic hepatitis $C$ virus infection, there was statistically significant difference ( $\mathrm{p}$-value $<0.05$ ) between (Bilirubin and Platelets) and there was highly statistical significant difference ( $\mathrm{p}$-value $<0.001$ ) between (AST, ALT, Liver stiffness and osteopontin) before and after therapy.

In patients with chronic hepatitis B virus infection, there were statistically significant difference ( $p$-value $<0.05$ ) between (liver stiffness and Platelets) before and after therapy while there was highly statistical significant difference ( $\mathrm{p}$-value $<0.001$ ) between (AST, ALT, Bilirubin, viral load and osteopontin) before and after therapy (Table 2).

In patients with chronic HCV no statistical significant difference (p-value > 0.05 ) between responders and non-responders to therapy as regard laboratory data and liver stiffness before therapy.

In patients with chronic hepatitis B virus infection, by comparing between responders and non-responders to therapy as regard pretreatment laboratory data (AST, Bilirubin, Albumin, Platelets, viral load and liver stiffness) showed 
Table 2. Comparisons between laboratory data before and after therapy in patients with chronic hepatitis $\mathrm{C}$ infection and chronic hepatitis B infection.

\begin{tabular}{|c|c|c|c|c|c|c|}
\hline \multirow[b]{2}{*}{ Variables } & \multicolumn{3}{|c|}{ Chronic hepatitis C infection } & \multicolumn{3}{|c|}{ Chronic hepatitis B infection } \\
\hline & $\begin{array}{c}\text { Before } \\
(\mathrm{N}=74)\end{array}$ & $\begin{array}{c}\text { After } \\
(\mathrm{N}=74)\end{array}$ & $\mathrm{p}$-value & $\begin{array}{c}\text { Before } \\
(\mathrm{N}=74)\end{array}$ & $\begin{array}{c}\text { After } \\
(\mathrm{N}=74)\end{array}$ & $\mathrm{p}$-value \\
\hline $\operatorname{AST}(\mathrm{U} / \mathrm{L})($ Mean $\pm \mathrm{SD})$ & $48.27 \pm 22.42$ & $27.50 \pm 38.89$ & $<0.001^{\star *}$ & $62.68 \pm 18.93$ & $31.80 \pm 15.88$ & $<0.001^{* *}$ \\
\hline $\operatorname{ALT}(\mathrm{U} / \mathrm{L})(\mathrm{Mean} \pm \mathrm{SD})$ & $51.62 \pm 26.07$ & $29.91 \pm 18.62$ & $<0.001^{\star *}$ & $67.72 \pm 21.81$ & $35.31 \pm 17.86$ & $<0.001^{* *}$ \\
\hline Bilirubin $(\mathrm{mg} / \mathrm{dl})($ Mean $\pm \mathrm{SD})$ & $1.11 \pm 0.29$ & $0.99 \pm 0.18$ & $0.005^{*}$ & $1.18 \pm 0.23$ & $1.06 \pm 0.13$ & $<0.001^{* *}$ \\
\hline Albumin $(\mathrm{g} / \mathrm{dl})($ Mean $\pm \mathrm{SD})$ & $4.08 \pm 0.64$ & $4.14 \pm 0.54$ & 0.5 & $3.99 \pm 0.52$ & $4.02 \pm 0.41$ & 0.6 \\
\hline Platelets $\left(\times 10^{3} / \mathrm{ul}\right)($ Mean $\pm \mathrm{SD})$ & $214.51 \pm 77.58$ & $254.27 \pm 75.03$ & $0.002^{*}$ & $213.84 \pm 73.81$ & $244.42 \pm 70.62$ & $0.01^{\star}$ \\
\hline $\operatorname{INR}($ Mean \pm SD $)$ & $1.07 \pm 0.16$ & $1.04 \pm 0.13$ & 0.3 & $1.08 \pm 0.15$ & $1.06 \pm 0.12$ & 0.5 \\
\hline Liver stiffness (kpa) $($ Mean \pm SD) & $7.36 \pm 3.26$ & $5.39 \pm 3.09$ & $<0.001^{\star *}$ & $7.19 \pm 3.11$ & $5.39 \pm 3.09$ & $0.001^{*}$ \\
\hline Osteopontin $($ Mean \pm SD) & $78.73 \pm 48.02$ & $51.43 \pm 30.17$ & $<0.001^{\star *}$ & $82.31 \pm 45.42$ & $54.26 \pm 31.51$ & $<0.001^{\star *}$ \\
\hline
\end{tabular}

*: p-value $<0.05$ is considered significant. ${ }^{* *}$ : p-value $<0.001$ is considered highly significant.

statistically significant difference ( $\mathrm{p}$-value $<0.05$ ), while there was post treatment highly statistical significant difference ( $\mathrm{p}$-value $<0.001$ ) between responders and non-responders to therapy as regard pretreatment laboratory data (INR and osteopontin). This is illustrated in (Table 3).

The mean pretreatment osteopontin level in patients with chronic HBV, HCV and control were $82.3 \pm 45.4,78.7 \pm 48.02$ and $13.2 \pm 6.4$ respectively with osteopontin level range from $7-31 \mathrm{ng} / \mathrm{ml}$ in apparent healthy control.

Using roc curve, it was shown that pretreatment high serum osteopontin can be used to predict failure of post treatment virological response to antiviral therapy and failure of achieving hepatic fibrosis regression in patients with chronic hepatitis B virus infection at a cutoff level of $>115.5 \mathrm{ng} / \mathrm{ml}$, with $90.91 \%$ sensitivity, $82.54 \%$ specificity, $83.9 \%$ PPV and $90.1 \%$ NPV.

Also using roc curve, it was shown that pretreatment high degree of liver stiffness value as evaluated by hepatic fibroscan can be used as a marker to predict failure of post treatment response to antiviral therapy in addition to failure of hepatic fibrosis regression in patients with chronic hepatitis B virus infection at a cutoff level of $>8.7$, with $81.8 \%$ sensitivity, $73 \%$ specificity, $75.2 \% \mathrm{PPV}$ and $80 \%$ NPV (Table 4, Figure 1 \& Figure 2).

However, in patients with chronic hepatitis $\mathrm{C}$ no role of pretreatment serum osteopontin to predict post treatment SVR or improvement in hepatic fibrosis.

\section{Discussion}

In humans Osteopontin is located on chromosome number 4, region 22 and it's composed of about 300 amino acids [25].

Osteopontin secretion is a marker to predict hepatic fibrosis in patients with hepatitis B virus or hepatitis $C$ virus infection [26]. 
Table 3. Comparisons between responders and non-responders as regard laboratory data before therapy in patients with chronic hepatitis $\mathrm{C}$ infection and chronic hepatitis B infection.

\begin{tabular}{|c|c|c|c|c|c|c|}
\hline \multirow{2}{*}{ Variables } & \multicolumn{3}{|c|}{ Chronic hepatitis $\mathrm{C}$ infection } & \multicolumn{3}{|c|}{ Chronic hepatitis B infection } \\
\hline & $\begin{array}{l}\text { Responders } \\
\qquad(\mathrm{N}=72)\end{array}$ & $\begin{array}{l}\text { Non-Responders } \\
\qquad(\mathrm{N}=2)\end{array}$ & $\mathrm{p}$-value & $\begin{array}{l}\text { Responders } \\
\quad(\mathrm{N}=63)\end{array}$ & $\begin{array}{l}\text { Non-Responders } \\
\qquad(\mathrm{N}=11)\end{array}$ & p-value \\
\hline $\operatorname{AST}(\mathrm{U} / \mathrm{L})($ Mean $\pm \mathrm{SD})$ & $49.50 \pm 38.89$ & $48.24 \pm 22.26$ & 0.9 & $60.52 \pm 19.15$ & $75.00 \pm 12.06$ & $0.02^{*}$ \\
\hline $\operatorname{ALT}(\mathrm{U} / \mathrm{L})($ Mean $\pm \mathrm{SD})$ & $53.00 \pm 42.43$ & $51.58 \pm 25.95$ & 0.9 & $66.10 \pm 22.17$ & $77.00 \pm 17.75$ & 0.1 \\
\hline Bilirubin (mg/dl) $($ Mean \pm SD) & $1.45 \pm 0.78$ & $1.10 \pm 0.27$ & 0.6 & $1.15 \pm 0.20$ & $1.38 \pm 0.30$ & $0.03^{*}$ \\
\hline Albumin (g/dl) $($ Mean \pm SD) & $3.75 \pm 1.06$ & $4.09 \pm 0.63$ & 0.7 & $4.06 \pm 0.47$ & $3.59 \pm 0.63$ & $0.005^{\star}$ \\
\hline Platelets $\left(\times 10^{3} / \mathrm{ul}\right)($ Mean \pm SD $)$ & $199.50 \pm 142.13$ & $214.93 \pm 76.79$ & 0.8 & $221.90 \pm 71.24$ & $167.64 \pm 74.47$ & $0.02^{*}$ \\
\hline INR $($ Mean \pm SD $)$ & $1.15 \pm 0.21$ & $1.06 \pm 0.16$ & 0.5 & $1.05 \pm 0.13$ & $1.23 \pm 0.18$ & $<0.001^{\star *}$ \\
\hline \multicolumn{7}{|l|}{ Viral load (N\%) } \\
\hline 1) Mild & $25(33.8 \%)$ & $0(0 \%)$ & & $25(39.7 \%)$ & $0(0 \%)$ & \\
\hline 2) Moderate & $25(33.8 \%)$ & $0(0 \%)$ & 0.1 & $23(36.5 \%)$ & $2(18.2 \%)$ & $0.001^{*}$ \\
\hline 3) High & $24(32.4 \%)$ & $2(100 \%)$ & & $15(23.8 \%)$ & $9(81.8 \%)$ & \\
\hline Liver stiffness $(\mathrm{kpa})($ Mean $\pm \mathrm{SD})$ & $7.90 \pm 6.93$ & $7.35 \pm 3.20$ & 0.8 & $6.84 \pm 2.94$ & $9.16 \pm 3.45$ & $0.02^{*}$ \\
\hline Osteopontin (Mean \pm SD) & $110.50 \pm 92.63$ & $77.85 \pm 47.13$ & 0.3 & $71.35 \pm 39.20$ & $145.09 \pm 21.07$ & $<0.001^{\star *}$ \\
\hline
\end{tabular}

*: p-value $<0.05$ is considered significant. ${ }^{* *}$ : p-value $<0.001$ is considered highly significant.

Table 4. Diagnostic performances of serum osteopontin and liver stiffness in discrimination of responder and non-responder of patients with chronic hepatitis B virus infection.

\begin{tabular}{cccccccc}
\hline Variables & Cut off & Area under the curve & Sensitivity & Specificity & PPV & NPV & p-value \\
\hline Osteopontin & $>115.5$ & 0.9 & $90.91 \%$ & $82.54 \%$ & $83.9 \%$ & $90.1 \%$ & $<0.001$ \\
Liver stiffness & $>8.7$ & 0.8 & $81.8 \%$ & $73 \%$ & $75.2 \%$ & $80 \%$ & 0.006 \\
\hline
\end{tabular}

PPV: positive predictive value; NPV: negative predictive value.

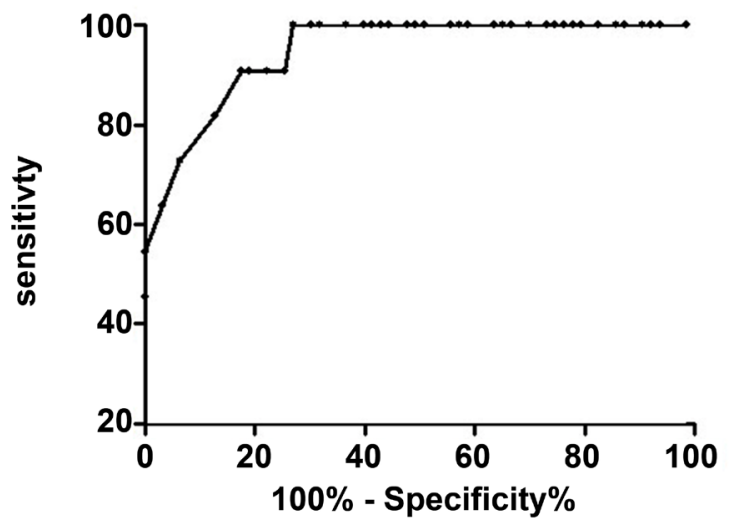

Figure 1. ROC curve between responder and non-responder as regard serum osteopontin in patients with chronic hepatitis B virus infection. 


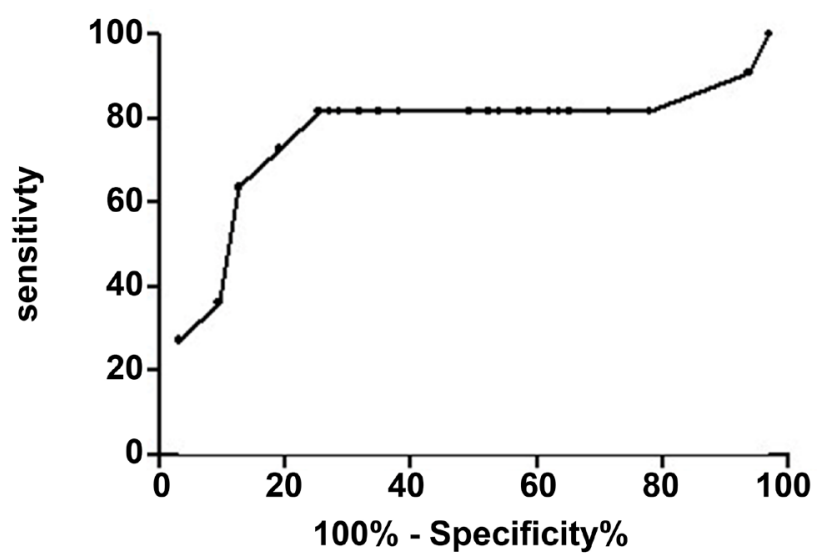

Figure 2. ROC curve between responder and non-responder in patients with chronic hepatitis B infection as regard liver stiffness.

In our study we try to evaluate the role of plasma Osteopontin level as a predictor of hepatic fibrosis regression and as a pretreatment marker that predict response to antiviral therapy.

In this study all included patients with chronic hepatitis B virus infection and chronic hepatitis $\mathrm{C}$ virus infection show marked improvement in liver function test, increase in platelets count and significant decrease in liver stiffness one year post $\mathrm{HBeAg}$ seroconversion and 3 months after regular antiviral therapy.

This come in agreement with Gai \& Wu, 2017 who found that there were marked improvement in liver function and reduction in liver fibrosis post Entecavir antiviral therapy in patients with chronic hepatitis B virus infection [27].

And Mohamed et al., 2017 reported marked improvement in liver function parameters and increase in platelets count post Sofosbuvir, daclatasvir plus ribavirin treatment in patients with chronic hepatitis $C$ virus infection [5].

Also Mehrez et al., 2017 found marked post treatment improvement in APRI and FIB-4 scores, liver enzymes and platelets count post Sofosbuvir and semiprevir antiviral therapy for 12 weeks [28]. And Shousha et al., 2017 conclude that 12 weeks therapy with Sofosbuvir contain regimen result in marked post treatment improving in hepatic fibrosis [29].

In this study we found no role of any pretreatment liver function laboratory parameters, platelet count, liver stiffness or serum Osteopontin as predictor of post treatment response treatment.

With our study, Mousa et al., 2017 found that no role of pretreatment HCV RNA in prediction of end treatment response or sustained virologic responses [30].

In contrast to our study Ahmed et al., 2018 found that in his patients who treated with sofosbuvir and daclatasvir with or without weight based ribavirin for 12 - 24 weeks that old age, cirrhosis, Child-turcotte-Pugh class B, and low thrombocyte count are independent risk factors of treatment non-response [31]. Also Khan et al., 2017 Our analysis suggests that AST enzyme levels $<30 \mathrm{u} / \mathrm{l}$ and AST: ALT ratio $<0.9$ are suitable substitutes for HCV RNA levels and good pre- 
dictor of treatment success following DAA (direct acting antiviral) therapies [32].

This may be related to small number of patients $2(2.7 \%)$ who failed to achieve SVR in our study.

In this study we found that pretreatment low serum albumin and low platelet count together with high level of serum AST, bilirubin, INR, viral load and marked hepatic fibrosis are pretreatment marker that predict failure of post treatment achievement of hepatic fibrosis regression and undetectable HBV DNA with $\mathrm{HBeAg}$ seroconversion.

In agreement with our result Myung et al., 2010 who found that $\mathrm{HBeAg}$ clearance and a low baseline HBV DNA level are predictor of high efficacy response to entecavir therapy in patients with chronic hepatitis B [33]. Against our study Huangetal, 2017 who found in his study on 162 patients with chronic hepatitis $B$, that no role of pretreatment liver enzymes, albumin, bilirubin, prothrombin time, platelets count or liver cirrhosis in predicting treatment response to entecavir therapy [34].

This can be explained by low number of patients 18 (11.1\%) who develop virological break through in his study.

In our study we found that no role of pretreatment serum osteopontin in predicting hepatic fibrosis regression or obtaining SVR post DAA therapy in patients with chronic hepatitis $\mathrm{C}$ virus infection. However, responder patients show higher pretreatment serum level compared to non-responder one with significant post treatment reduction in serum osteopontin level.

With our result Choi et al., 2014 reported that in patients infected with HCV, osteopontin may directly promote HCV replication [35].

Also study done by Iqbal et al., 2013 demonstrated that, HCV-induced osteopontin activation [36].

In our study we have significant higher level of pretreatment serum osteopontin in non-responder patients compared with responder one. Also we found that low pretreatment serum osteopontin has a high efficacy in predicting post treatment hepatic fibrosis regression and effective virologicl response to entecavir antiviral therapy with undetectable HBV-DNA and HBeAg seroconversion in patients with chronic hepatitis B virus infection at a cutoff level of $<115.5 \mathrm{ng} / \mathrm{ml}$, with high sensitivity and specificity.

This come in agreement with Liu et al., 2017 who reported that low serum osteopontin may be a predictor of good prognosis in patients with chronic hepatitis B virus infection but high serum osteopontin directly correlate with liver cell injury [37].

In this study we also found that pretreatment low degree of hepatic fibrosis is a good marker that predicts post treatment hepatic fibrosis regression in chronic hepatitis B virus infected patients at a cutoff level of $<8.7$, but with lower sensitivity and specificity compared to serum osteopontin.

This come in agreement with Chon et al. 2017 who concluded that low pre- 
treatment liver stiffness value $(<12.0 \mathrm{kPa})$ was a significant predictor of fibrosis improvement in patients with chronic hepatitis B virus infection [38].

In conclusion: pretreatment low serum osteopontin in addition to early hepatic fibrosis were predictor of good prognosis in patients with chronic HBV infection with good virological response and hepatic fibrosis regression. Although, pretreatment serum osteopontin level was higher in chronic hepatitis $C$ virus infected patients than post treatment one. But it had no role in predicting post treatment SVR or hepatic fibrosis regression. Further studies on large number of patients are needed to evaluate its role as prognostic marker in chronic hepatitis $\mathrm{C}$ virus infected patients.

\section{Conflicts of Interest}

The authors declare no conflicts of interest regarding the publication of this paper.

\section{References}

[1] Kouyoumjian, S.P., Chemaitelly H. and Abu-Raddad, L.J. (2018) Characterizing Hepatitis C Virus Epidemiology in Egypt: Systematic Reviews, Meta-Analyses, and Meta-Regressions. Scientific Reports, 8, Article No. 1661. https://doi.org/10.1038/s41598-017-17936-4

[2] Westbrook, R.H. and Dusheiko, G. (2014) Natural History of Hepatitis C. Journal of Hepatology, 61, S58-S68. https://doi.org/10.1016/j.jhep.2014.07.012

[3] Abdel-Moneim, A., Aboud, A., Abdel-Gabaar, M., Zanaty, M.I. and Ramadan, M. (2018) Efficacy and Safety of Sofosbuvir Plus Daclatasvir with or without Ribavirin: Large Real-Life Results of Patients with Chronic Hepatitis C Genotype 4. Hepatology International, 12, 348-335. https://doi.org/10.1007/s12072-018-9868-8

[4] Omar, H., et al. (2018) Generic Daclatasvir Plus Sofosbuvir, with or without Ribavirin, in Treatment of Chronic Hepatitis C: Real-World Results from 18378 Patients in Egypt. Alimentary Pharmacology \& Therapeutics, 47, 421-431. https://doi.org/10.1111/apt.14428

[5] Mohamed, M.S., Hanafy, A.S., Bassiony, M.A.A. and Hussein, S. (2017) Sofosbuvir and Daclatasvir Plus Ribavirin Treatment Improve Liver Function Parameters and Clinical Outcomes in Egyptian Chronic Hepatitis C Patients. European Journal of Gastroenterology \& Hepatology, 29, 1368-1372. https://doi.org/10.1097/MEG.0000000000000963

[6] Ismail, S.A., et al. (2017) Hepatitis B in Egypt: A Cross-Sectional Analysis of Prevalence and Risk Factors for Active Infection from a Nationwide Survey. Liver International, 37, 1814-1822. https://doi.org/10.1111/liv.13469

[7] Lai, C.L., Ratziu, V., Yuen, M.F. and Poynard, T. (2003) Viral Hepatitis B. The Lancet, 362, 2089-2094. https://doi.org/10.1016/S0140-6736(03)15108-2

[8] Pawlotsky, J.M., et al. (2008) Virologic Monitoring of Hepatitis B Virus Therapy in Clinical Trials and Practice: Recommendations for a Standardized Approach. Gastroenterology, 134, 405-415. https://doi.org/10.1053/j.gastro.2007.11.036

[9] Zhang, Q.Q., et al. (2011) Long-Term Nucleos(t)ide Analogues Therapy for Adults with Chronic Hepatitis B Reduces the Risk of Long-Term Complications: A Meta-Analysis. Virology Journal, 8, 72. https://doi.org/10.1186/1743-422X-8-72 
[10] Maklad, S., Reyad, E. M., William, E. A. and Abouzeid A. (2018) Effcacy and Safety of Entecavir $0.5 \mathrm{mg}$ in Treating Naïve Chronic Hepatitis B Virus Patients in Egypt: Five Years of Real Life Experience. Gastroenterology Research, 11, 138-144. https://doi.org/10.14740/gr965w

[11] Biçer, K.Ç., Ari, A., Genç, V.E., Caymaz, S.Ö., Avci, M. and Bal, F. (2015) Efficacy of Entecavir Treatment among Chronic Hepatitis B Nucleos(t)ide-Naive and -Experienced Patients. Turkish Journal of Medical Sciences, 45, 99-104. https://doi.org/10.3906/sag-1309-78

[12] Choi, H.N., Song, J.E., Lee, H.C., Jo, H.H., Lee, C.H. and Kim, B.S. (2015) Efficacy of Prolonged Entecavir Monotherapy in Treatment-Naive Chronic Hepatitis B Patients Exhibiting a Partial Virologic Response to Entecavir. Clinical and Molecular Hepatology, 21, 24-31. https://doi.org/10.3350/cmh.2015.21.1.24

[13] Senger, D.R., Wirth, D.F. and Hynes, R.O. (1979) Transformed Mammalian Cells Secrete Specific Proteins and Phosphoproteins. Cell, 16, 885-893.

https://doi.org/10.1016/0092-8674(79)90103-X

[14] Brown, L.F., Berse, B., Van de Water, L., Papadopoulos-Sergiou, A., Perruzzi, C.A., Manseau, E.J., et al. (1992) Expression and Distribution of Osteopontin in Human Tissues: Widespread Association with Luminal Epithelial Surfaces. Molecular Biology of the Cell, 3, 1169-1180. https://doi.org/10.1091/mbc.3.10.1169

[15] Kawashima, R., et al. (1999) Expression of Osteopontin in Kupffer Cells and Hepatic Macrophages and Stellate Cells in Rat Liver after Carbon Tetrachloride Intoxication: A Possible Factor for Macrophage Migration into Hepatic Necrotic Areas. Biochemical and Biophysical Research Communications, 256, 527-531. https://doi.org/10.1006/bbrc.1999.0372

[16] Srungaram, P., Rule, J.A., Yuan, H.J., Reimold, A., Dahl, B., Sanders, C., et al. (2015) Plasma Osteopontin in Acute Liver Failure. Cytokine, 73, 270-276. https://doi.org/10.1016/j.cyto.2015.02.021

[17] Yilmaz, Y., et al. (2013) Serum Osteopontin Levels as a Predictor of Portal Inflammation in Patients with Nonalcoholic Fatty Liver Disease. Digestive and Liver Disease, 45, 58-62. https://doi.org/10.1016/j.dld.2012.08.017

[18] Patouraux, S., Bonnafous, S., Voican, C.S., Anty, R., Saint-Paul, M.C., Rosenthal-Allieri, M.A., et al. (2012) The Osteopontin Level in Liver, Adipose Tissue and Serum is Correlated with Fibrosis in Patients with Alcoholic Liver Disease. PLoS ONE, 7, e35612. https://doi.org/10.1371/journal.pone.0035612

[19] Zhao, L., Li, T., Wang, Y., Pan, Y., Ning, H., Hui, X., et al. (2008) Elevated Plasma Osteopontin Level Is Predictive of Cirrhosis in Patients with Hepatitis B Infection. International Journal of Clinical Practice, 62, 1056-1062. https://doi.org/10.1111/j.1742-1241.2007.01368.x

[20] Matsue, Y., Tsutsumi, M., Hayashi, N., Saito, T., Tsuchishima, M., Toshikuni, N., et al. (2015) Serum Osteopontin Predicts Degree of Hepatic Fibrosis and Serves as a Biomarker in Patients with Hepatitis C Virus Infection. PLOS ONE, 10, e0118744. https://doi.org/10.1371/journal.pone.0118744

[21] Shang, S., Plymoth, A., Ge, S., Feng, Z., Rosen, H.R., Sangrajrang, S., et al. (2012) Identification of Osteopontin as a Novel Marker for Early Hepatocellular Carcinoma. Hepatology, 55, 483-490. https://doi.org/10.1002/hep.24703

[22] Friedman, S.L. (2000) Molecular Regulation of Hepatic Fibrosis, an Integrated Cellular Response to Tissue Injury. The Journal of Biological Chemistry, 275, 2247-2250. https://doi.org/10.1074/jbc.275.4.2247

[23] European Association for the Study of the Liver (2017) EASL 2017 Clinical Practice 
Guidelines on the Management of Hepatitis B Virus Infection. Journal of Hepatology, 67, 370-398. https://doi.org/10.1016/j.jhep.2017.03.021

[24] European Association for the Study of the Liver (2015) EASL Recommendations on Treatment of Hepatitis C 2015. Journal of Hepatology, 63, 199-236. https://doi.org/10.1016/j.jhep.2015.03.025

[25] Denda, S., Reichardt, L.F. and Muller, U. (1998) Identification of Osteopontin as a Novel Ligand for the Integrin $\alpha 8 \beta 1$ and Potential Roles for this Integrin-Ligand Interaction in Kidney Morphogenesis. Molecular Biology of the Cell, 9, 1425-1435. https://doi.org/10.1091/mbc.9.6.1425

[26] Pereira, T.A., Syn, W.K. Machado, M.V., Vidigal, P.V., Resende, V., Voieta, I., et al. (2015) Schistosome-Induced Cholangiocyte Proliferation and Osteopontin Secretioncorrelate with Fibrosis and Portal Hypertension in Human and Murineschistosomiasis Mansoni. Clinical Science, 129, 875-883. https://doi.org/10.1042/CS20150117

[27] Gai, X.-D. and Wu, W.-F. (2017) Effect of Entecavir in the Treatment of Patients with Hepatitis Bvirus-Related Compensated and Decompensated Cirrhosis. Experimental and Therapeutic Medicine, 14, 3908-3914. https://doi.org/10.3892/etm.2017.4963

[28] Mehrez, M.I., Saleh, M.A. and Fareid, A. (2017) Fibrosis Regression after Treatment with Daas. Gastroenterology \& Hepatology: Open Access (GHOA), 7, 00223. https://doi.org/10.15406/ghoa.2017.07.00223

[29] Shousha, H.I., Mehassab, M.K., Mehrez, M.I., Afifi, S.A, Elsharkawy, M., Hamed, M. and Abdelaziz, R.A. (2017) Non-Invasive Fibrosis Scores and Liver Stiffness Changes in Chronic Hepatitis C after Sofosbuvir-Based Treatment. International Journal of Hepatology \& Gastroenterology, 3, 85-90.

[30] Mousa, O.Y., Kim, C.H., Pham, L.E., Zela, S.A., Egwim, C. and Sey, V.A. (2017) Predictors of Sustained Virologic Response and Failure of First DAA Terapy in Chronic Hepatitis C Patients. SM Journal of Hepatitis Research and Treatment, 3, 10-14.

[31] Ahmed, O.A., et al. (2018) Outcomes and Predictors of Treatment Response with Sofosbuvir plus Daclatasvir with or without Ribavirin in Egyptian Patients with Genotype 4 Hepatitis C Virus Infection. Infection and Drug Resistance, 11, 441-445. https://doi.org/10.2147/IDR.S160593

[32] Khan, S.T., McGuinty, M., Corsi, D.J. and Cooper, C.L. (2017) Liver Enzyme Normalization Predicts Success of Hepatitis C Oral Direct Acting Antiviral Treatment. Clinical and Investigative Medicine, 40, E73-E80.

https://doi.org/10.25011/cim.v40i2.28198

[33] Myung, H.J., Jeong, S.H., Kim, J.W., Kim, H.S., Jang, J.H., Lee, D.H., Kim, N., Hwang, J.H., Park, Y.S. and Lee, S.H. (2010) Efficacy and Predictors of the Virologic Response to Entecavir Therapy in Nucleoside-Naive Patients with Chronic Hepatitis B. The Korean Journal of Hepatology, 16, 57-65.

https://doi.org/10.3350/kjhep.2010.16.1.57

[34] Huang, Y.-J., Chang, C.-S., Peng, Y.-C., Yeh, H.-Z. and Yang, S.-S. (2017) On-Treatment HBV DNA Dynamics Predict Virological Breakthrough in Entecavir-Treated HBeAg-Positive Chronic Hepatitis B. PLoS ONE, 12, e0174046. https://doi.org/10.1371/journal.pone.0174046

[35] Choi, S.S., Claridge, L.C., Jhaveri, R., Swiderska-Syn, M., Clark, P., Suzuki, A., et al. (2014) Osteopontin Is Up-Regulated in Chronic Hepatitis C and Is Associated with Cellular Permissiveness for Hepatitis C Virus Replication. Clinical Science, 126, 
845-855. https://doi.org/10.1042/CS20130473

[36] Iqbal, J., McRae, S., Banaudha, K., Mai, T. and Waris, G. (2013) Mechanism of Hepatitis C Virus (HCV) -Induced Osteopontin and Its Role in Epithelial to Mesenchymal Transition of Hepatocytes. Journal of Biological Chemistry, 288, 36994-37009. https://doi.org/10.1074/jbc.M113.492314

[37] Liu, L., Lu, J., Ye, C., Lin, L., Zheng, S., Zhang, H., Lan, Q. and Xue, Y. (2018) Serum Osteopontin Is a Predictor of Prognosis for HBV-Associated Acute-on-Chronic Liver Failure. Biomedical Reports, 8, 166-171.

[38] Chon, Y.E., et al. (2017) Improvement of Liver Fibrosis after Long-Term Antiviral Therapy Assessed by Fibroscan in Chronic Hepatitis B Patients with Advanced Fibrosis. The American Journal of Gastroenterology, 112, 882-891.

https://doi.org/10.1038/ajg.2017.93 